Paper received: June $26^{\text {th }} 2015$

Paper accepted: September $22^{\text {nd }} 2015$

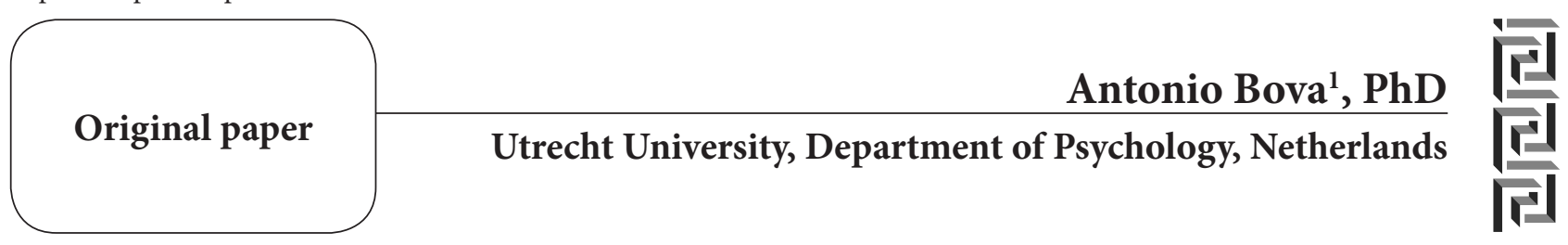

DOI:10.5937/inovacije1503130B

\title{
Promoting learning and development of students through argumentative interactions. A study of the teacher's questions in the learning contexts of higher education
}

\begin{abstract}
This study sets out to investigate how learning and development of students through social interaction in the classroom can be pursued by the teacher in the learning contexts of higher education. The aim of this study is to compare the types of teachers' questions to their students used at undergraduate and graduate levels during argumentative disciplinary discussions in the classroom. The data corpus is constituted by 16 video-recorded lessons of two courses - one at undergraduate level and one at graduate level - in Developmental Psychology. The two courses were selected according to the following criteria: i) similar number of students, ii) similar disciplinary domain, iii) both courses are taught by the same teacher in English language. The analytical approach adopted for the analysis relies on a qualitative methodology based on the pragma-dialectical ideal model of a critical discussion. The findings of this study indicate that at the undergraduate level the teacher asks questions that can favour a large discussion with and among students around general topics relating to Developmental Psychology. At the graduate level the teacher asks questions that refer to specific aspects of a certain theory. However, both at undergraduate and graduate level the students are expected to provide the reasons at the basis of their own opinions by advancing arguments that have to refer to scientific theories. The results of this study bring to light the crucial role played by the teacher in promoting learning and development of students, by favouring the beginning of argumentative discussions with and among them on topics relating to the discipline taught in the course.
\end{abstract}

Key words: Argumentation; Higher Education; Qualitative Research; Student-Teacher Interaction; Teacher's Questions.

\section{Introduction}

A clear goal of the actual reform movement in science education in EU is to encourage the growth of the argumentative skills of students through teaching practices that foster and facilitate argumentative discussions in the classroom.

Since argumentation and discourse are central to the work of scientists, their role in science teacher education is relevant since teachers need to emulate and facilitate both in their class-

1 A.Bova@uu.nl 
rooms. In addition, both contribute to a pedagogically relevant socio-cultural framework for learning and can precipitate the active constructivism which can help students take ownership over their learning. (Eurydice ${ }^{1}, 2011$, p.105)

In line with this new, strong focus within educational policy, the research on argumentation in science education has been intensified considerably, attracting growing attention "as a linguistic, logical, dialogical, and psychological process that sustains or provokes reasoning and learning" (Muller Mirza \& Perret-Clermont, 2009, p.1). From primary school to the academic context, students encounter issues and positions that need to be developed, defended or evaluated (Buty \& Plantin, 2008; Erduran \& JiménezAleixandre, 2007; López-Facal et al., 2015; Schwarz, 2009). Argumentation enables students to engage in knowledge construction, shifting the focus from rote memorization of notions and theories to a complex scientific practice in which they construct and justify knowledge claims (Kelly \& Chen, 1999; Sandoval \& Reiser, 2004). However, in contrast to argumentation in informal settings such as family mealtimes (Bova \& Arcidiacono 2014, 2015), argumentation in the learning contexts rarely occurs spontaneously. The argumentative disciplinary discussions in the classroom are to be explicitly promoted through teaching strategies that support student-to-student and student-to-teacher interactions (Hogan \& Maglienti, 2001; Simon et al., 2006; Zohar \& Nemet, 2002). Accordingly, the role of the teacher is crucial to foster students' engagement in argumentation.

The present study intends to provide a further contribution to the recent literature on argumentation in the learning contexts of higher education. It specifically centers on the teacher's questions to their students during argumentative disciplinary discussions in the classroom, i.e., task-related discussions concerning the discipline taught in the course. In line with other scholars (Kuhn, 1991; Voss \& van Dyke, 2001), I refer to an individual argument as a product and to the argumentative discussion as a process, the latter being implicit in the former. That being said, it is not a goal of the present study to make an assessment of the argumentative discussions occurring in the classroom between students and teacher, i.e. deciding whether or not the arguments advanced respect logical criteria. Rather, the goal is to compare the types of questions asked by the teacher to undergraduate and graduate students during argumentative disciplinary discussions in the classroom.

The data corpus on which the present study is based is composed of sixteen video-recorded separate lessons of one Bachelor's degree and one Master's degree course. In order to focus on the teacher's questions, the object of investigation will be the argumentative discussions between students and teacher, as well as among students, occurring during their ordinary lessons, rather than an ad hoc setting created to favor the beginning of argumentative discussions. The analytical approach for the identification of the argumentative discussions is the pragmadialectical ideal model of a critical discussion (van Eemeren \& Grootendorst, 2004). This model proposes an ideal definition of argumentation developed according to the standard of reasonableness: an argumentative discussion starts when the speaker advances his/her standpoint, and the listener casts doubts upon it, or directly attacks the standpoint. Accordingly, confrontation, in which disagreement regarding a certain standpoint is externalized in a discursive exchange or anticipated by the speaker, is a necessary condition for an argumentative discussion to occur. This model particularly fits this study, and more generally, the study of argumentative interactions occurring in ordinary contexts, because it provides specific criteria in order to select and identify the argumentative discussions.

The present paper is structured as follows: in Section 2, a concise review of the most relevant literature on argumentation in learning contexts of higher education will be presented. In Section 3, the methodology on which the present study is based will be described. The results of the analysis are dis- 
cussed in Section 4, followed by the Section 5, which summarizes the main findings and comments on their limitations and strengths.

\section{Argumentation studies in learning contexts of higher education}

Over recent years, several studies have been devoted to examine the conditions which can favor or disfavor the creation of effective argumentative activities at a primary and middle school level (Baker, 2002; Duschl \& Osborne, 2002; JiménezAleixandre, 2007; Sadler, 2006), to establish which criteria must be included in assessing the argumentative skills of pupils and students (Anderson et al., 1997; Garcia-Mila \& Andersen, 2007; Muller Mirza et al., 2009), and how to further improve these skills (Kuhn \& Udell, 2003; Nussbaum \& Schraw, 2007; Schwarz \& Linchevski, 2007; Zohar \& Nemet, 2002). Despite fewer in number, the works focused on the learning contexts of higher education too have brought to light relevant insights in the fields of education and argumentation theory.

Overall, the results of these studies indicate that in the learning contexts of higher education the role of the teacher is essential for engaging students in argumentation (McNeill \& Krajcik, 2009), by favoring argumentative debates in the classroom and enhancing students' motivation (Chin \& Osborne, 2010), and helping them detect and resolve errors (Schwarz et al., 2000). A series of other studies have shown that engagement in constructing arguments enhances students' knowledge by promoting conceptual change (e.g., Nussbaum \& Sinatra, 2003; Wiley \& Voss, 1999), and that the engagement in argumentative small- or large-group discussions improves conceptual understanding (e.g., Alexopoulou \& Driver, 1996; Andrews, 2009; Mason, 2001). The role of argumentation in the academic context is also currently stressed by a growing literature that emphasizes the problem of constructing students' knowledge taking into account their level of knowledge of the topic under consideration (Driver et al., 2000; Jiménez-Aleixandre et al., 2000; Kelly \& Takao, 2002; Macagno \& Konstantinidou, 2013; Osborne, 2005; Sampson \& Clark, 2008). In this regard, it has been documented that previous knowledge in the domain is a significant predictor of comprehension of the arguments advanced within a scientific text (e.g., Alexander et al., 1994; Means \& Voss, 1996).

The two major points highlighted by the previous studies on argumentation in the learning contexts of higher education, i.e., the crucial role played by the teacher for engaging students in argumentation and the importance of taking into account the students' level of knowledge of the discipline taught in the course, lead us to focus on two fundamental questions from an educational and learning perspective: (i) "How do the teachers promote and manage argumentation with and among students in classes of different levels?". And (ii) "Do they adapt their teaching style to their students' level of knowledge of the discipline taught in the course?". In order to answer these questions, the present study focuses on the teacher's questions to their students during argumentative disciplinary discussions in the classroom, i.e., task-related discussions concerning the discipline taught in the course, with the aim to compare the types of questions asked at undergraduate level and at graduate level.

The choice to center the present investigation on the teacher's questions to the students stems from the crucial role played by questions in triggering argumentative discussions, as amply demonstrated in the literature on argumentation in different spheres of activities. For example, in a study on the argumentative practices in the family context, Bova and Arcidiacono (2013) have shown that the why-questions asked by children to their parents have not only an explanatory function, i.e., asking for an explanation of the reasons at the basis of a fact or event, but also an argumentative function. According to the authors, this type of question challenges parents to 
justify their rules and prescriptions, which remain frequently implicit or based on rules not initially known by or previously made explicit to children. Similar results were also found by Chouinard et al. (2007) and Frazier et al. (2009). In a similar vein, Chin and Osborne (2010), in a study focused on the verbal interactions among students aged 12-14 years during group discussions concerning scientific topics, showed that the most significant contributions of students' questions is their potential in scaffolding students' argument construction by eliciting the epistemic features of explanations with requests for "data", "evidence", and "counter-arguments". According to these authors, students' questions serve as triggers to enable argumentative and epistemic moves, such as concessions, challenges and counter-challenges, which subsequently led to the construction of more elaborate explanations and justifications, as well as to changes in the standpoints of members who modified their initial conceptions.

Thus far, the attention of educationists and psychologists has been mainly devoted to investigate the questions asked by children and students. Shifting the focus from students' questions to teacher's questions during argumentative disciplinary discussions in the classroom, the present study intends to provide a further contribution to the recent literature on argumentation in the learning contexts of higher education. In the next sections of the paper I will present the research design, as well as the main results of the study.

\section{Methodology}

\section{Data Corpus}

The data corpus is composed of sixteen video-recorded separate lessons (constituting about 24 hours of video data) of one Bachelor's degree (subcorpus 1) and one Master's degree course (sub-corpus 2). The length of each recording varies from 84 to 98 minutes. The two courses have been selected according to the following criteria: i) similar num- ber of students (about 15 students); ii) similar disciplinary domain (both courses considered handle are in the area of developmental psychology); iii) both courses are taught by the same teacher in English language.

Sub-corpus 1 consists of 8 video-recorded lessons of the third year elective course "Adolescent Development: Research, Policy, and Practice" of the Bachelor's degree at the University College of Utrecht (UCU). The sub-corpus 1 is constituted by 14 students, 4 boys and 10 girls. All the students at the time of data collection were in their early $20 \mathrm{~s}(\mathrm{M}=$ $21.80 ; \mathrm{SD}=1.80)$. There was no significance difference of age between boys $(M=21.89 ; S D=2.66)$ and girls $(M=21.74$; $S D=1.20)$.

Sub-corpus 2 consists of 8 video-recorded lessons of the first year elective course "Human development and developmental psychopathology" of the Master's degree program Development and Socialization in Childhood and Adolescence (DASCA) at the Utrecht University (UU). The sub-corpus 2 is constituted by 16 students, who were all girls. Most of the students at the time of data collection were in their early 20s $(\mathrm{M}=23.00$; $\mathrm{SD}=1.60)$.

\section{Students' level of knowledge of the discipline}

Before starting the first lesson of the course (December 2013), both undergraduate and graduate students were asked by their teacher (i) to rate in a scale from 1 (none) to 9 (excellent) their own ability to communicate in English language, (ii) if they had already took an academic course in Developmental Psychology, and (iii) to rate in a scale from 1 (none) to 9 (excellent) the level of their previous knowledge in Developmental Psychology, i.e., before taking the course (see Appendix A). As for the ability to communicate in English language, in a scale from 1 to 9 the average score of the undergraduate students, according to their own perception, was $M=8.28$, while the average score of the graduate students was slightly lower $M=7.56$. The most part of the students did already take an academic course in Devel- 
opmental Psychology, both undergraduate (Yes N= 12; No $\mathrm{N}=2$ ) and graduate level (Yes $\mathrm{N}=15$; $\mathrm{No} \mathrm{N}=$ 1). As for the level of their previous knowledge of the discipline taught in the course, in a scale from 1 to 9 the average score of the undergraduate students, according to their own perception, was slightly lower $(M=6.35)$ than graduate students $(M=7.25)$.

Detailed information on the information obtained from the questionnaire are presented below, in Table 1:

\begin{tabular}{|l|l|l|}
\hline & Bachelor & Master \\
\hline $\begin{array}{l}\text { Students' own perception of } \\
\text { their ability to communicate } \\
\text { in English - in a scale from 1 } \\
\text { (none) to 9 (excellent) }\end{array}$ & 8.28 & 7.56 \\
\hline $\begin{array}{l}\text { Students who already took } \\
\text { a course in Developmental } \\
\text { Psychology }\end{array}$ & Yes N =12 & Yes N $=15$ \\
\hline $\begin{array}{l}\text { Students' own perception } \\
\text { of their knowledge in } \\
\text { Developmental Psychology } \\
\text { before the beginning of the } \\
\text { course - in a scale from 1 } \\
\text { (none) to 9 (excellent) }\end{array}$ & 6.35 & 7.25 \\
\hline
\end{tabular}

Table 1. Information obtained from the questionnaire administered to bachelor and master students

\section{Transcription Procedures and Ethical Issues}

All lessons have been transcribed in their totality with the CHILDES standard transcription system (CHAT) (MacWhinney, 2000), with some modifications introduced to enhance readability (see Appendix), and revised by two researchers until a high level of consent (agreement rate $=90 \%$ ) has been reached. All turns have been numbered progressively within the discussion sequence, and participants are identified by role for the teacher (e.g., TEACH) and by role, number, and gender for student (e.g., STU1M, STU2F, STU3F, etc.).

The ethical framework that guides this research includes informed consent from the partici- pants, anonymity and confidentiality. All participants were approached by means of an information sheet outlining in clear language the general purpose of the study and providing information about how the video data would be used. Consent letters have been written in accordance with Dutch Association of Psychologists (NIP) and American Psychological Association (APA) guidelines, specifically, the format outlined in the fifth edition of the Publication Manual of the American Psychological Association (APA, 2009). In line with the ethical framework guiding the research, the students were assured that their anonymity would be maintained at all stages of the study. Transcriptions and video-recorded material have been treated in the strictest confidence and seen only by researchers.

\section{Analytical Approach}

\section{The ideal model of a critical discussion}

The analytical approach adopted for the analysis is the pragma-dialectical ideal model of a critical discussion (van Eemeren \& Grootendorst, 2004). This approach considers that argumentative speech acts are not performed in a social vacuum, but between two or more parties who are having a disagreement and interact with each other in an attempt to resolve this disagreement. The pragma-dialectical ideal model of a critical discussion spells out four stages that are necessary for a dialectical resolution of differences of opinion between a protagonist that advances and sustains a standpoint and an antagonist that assesses it critically: at the confrontation stage, it is established that there is a dispute. A standpoint is advanced and questioned; at the opening stage, the decision is made to attempt to resolve the dispute by means of a regulated argumentative discussion. One party takes the role of protagonist, and the other party takes the role of antagonist; at the argumentation stage, the protagonist defends his/her standpoint and the antagonist elicits further argumentation from him/her if he/she has further doubts; at the concluding stage, it is established 
whether the dispute has been resolved on account of the standpoint or the doubt concerning the standpoint having been retracted.

In the present study, the ideal model of a critical discussion is assumed as a grid for the analysis since it provides the criteria for the selection of the argumentative discussions.

\section{Selection of argumentative discussions}

For the present study, only the discussions that fulfill two of the following three criteria, one between i.a and i.b and always the ii., have been considered as an argumentative discussion:

i.a at least one standpoint concerning an issue related to the discipline taught in the course put forth by one or more students is questioned - either by means of a clear disagreement or by means of a doubt - by the teacher or by (at least) one classmate.

$i . b$ at least one standpoint concerning an issue related to the discipline taught in the course put forth by the teacher is questioned - either by means of a clear disagreement or by means of a doubt - by one or more students.

ii. at least one student advances at least one argument either in favor of or against the standpoint being questioned.

\section{Identification of the types of questions}

The argumentation data for each session were obtained by reviewing both the video recording and the corresponding transcript. For the scope of the present study, all the questions asked by the teacher to their students during the argumentative disciplinary discussions in the classroom were selected $(\mathrm{N}=272)$. Once identified, the questions asked by the teacher were distinguished according to the following criteria:

- the question refers to broad topics in the field of Developmental Psychology (hereafter, BROAD QUESTION), e.g. What are the main reasons leading to episodes of bullying among adolescents?

- the question refers to a specific theory or to a certain aspect of a theory in the field of Developmental Psychology (hereafter, SPECIFIC QUESTION), e.g. Which developmental processes can be studied by each of the seven models described by Graber and Brooks-Gunn and how?

\section{Results}

In the corpus, $\mathrm{N}=94$ argumentative discussions, $\mathrm{N}=59$ at graduate level and $\mathrm{N}=35$ at undergraduate level, were found. The total number of questions asked by the teacher to their students during the argumentative disciplinary discussions in the classroom was $\mathrm{N}=272$. The analysis of the questions asked by the teacher to their undergraduate students involved $\mathrm{N}=35$ argumentative discussions for a total number of $\mathrm{N}=121$ questions, while the analysis of the questions asked by the teacher to their graduate students involved $\mathrm{N}=59$ argumentative discussions for a total number of $\mathrm{N}=161$ questions (see Table 2).

\begin{tabular}{|c|c|c|c|}
\hline & Bachelor & Master & TOTAL \\
\hline Number of argumentative discussions & 35 & 59 & 94 \\
\hline Arguments put forth by students & 75 & 167 & 242 \\
\hline Average number of arguments advanced during an argumentative discussion & 3.26 & 3.88 & 3.66 \\
\hline $\begin{array}{l}\text { Teacher's questions to their students during the argumentative disciplinary } \\
\text { discussions in the classroom }\end{array}$ & 121 & 161 & 282 \\
\hline $\begin{array}{l}\text { Average number of teacher's questions to their students during the argumentative } \\
\text { disciplinary discussions in the classroom }\end{array}$ & 3.45 & 2.72 & 2.89 \\
\hline
\end{tabular}

Table 2. Contributions of students and teacher in argumentative discussions in the classroom 
In order to present the results of this study, a selection of excerpts of talk-in-interaction representative of the results obtained from the larger set of analyses conducted on the whole corpus of teacher's questions will be presented.

\section{Analysis of the teacher's questions}

The findings show that in large part the teacher asked questions that can favor a large discussion with and among students around general topics relating to Developmental Psychology (BROAD QUESTIONS) to her undergraduate students ( $\mathrm{N}=$ $87 ; 72 \%)$. The following excerpt presents a clear illustration of the use of this type of question by the teacher.

\section{Excerpt 1}

Lesson 3. Min. 38:12. Participants: teacher (TEACH), students (STU2F; STU14M).

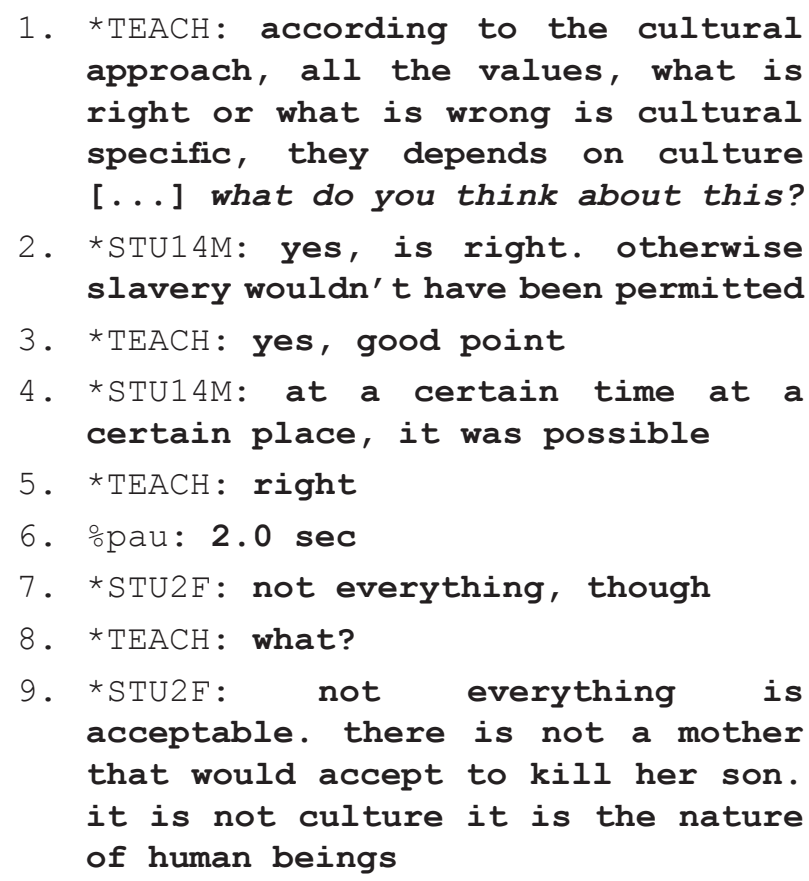

In this example we can observe how the teacher asked a BROAD QUESTION (line 1, in Italic in the excerpt: "what do you think about this?") to her undergraduate students in order to favour the beginning of a discussions among them around a general topic related to Developmental Psychology, i.e., the cultural approach and its implications. With this question, the teacher favours a large discussion in the classroom since the students are not requested to have a detailed knowledge of the cultural approach to participate in this discussion. Not by chance, subsequently we can see that the students actually engage in an argumentative discussion. The student STU2F put forth an argument (line 9) to oppose another argument (line 2 and line 4 ) previously advanced by one of her classmate (STU14M).

In the corpus, the teacher asked only in few occasions SPECIFIC QUESTIONS to her undergraduate students $(\mathrm{N}=34 ; 28 \%)$. These questions were typically asked by the teacher when the argumentative discussion was started and the students had already advanced their opposite standpoints. The goal of these questions was, in fact, not to favour the beginning of a new discussion among students but rather the continuation of a pre-existing discussion.

Similarly to what was observed with regard to the undergraduate students, the BROAD QUESTIONS ( $\mathrm{N}=65 ; 40 \%)$ were in most cases asked by the teacher to graduate students to favor the beginning of a new discussion among them. On the other hand, differently from what was observed for undergraduate students the findings indicate that more than half of the times the teacher asked SPECIFIC QUESTIONS to her graduate students $(\mathrm{N}=96$; $60 \%$ ). The following excerpt presents a clear illustration of the use of this type of question by the teacher.

\section{Excerpt 2}

Lesson 6. Min. 32:15. Participants: teacher (TEACH), student (STU7F; STU14F).

1. ${ }^{\mathrm{TEACH}}$ : we talked about the risk of
drug abuse, drinking, unprotected
sex 
Promoting learning and development of students through argumentative interactions....

2. *STU7F: it is a risky development phase

3. *STU14F: sure, there are many risk behaviours in this phase ( (adolescence))

4. ${ }^{\mathrm{TEACH}}$ : what are the most important processes that according to Steinberg and Morris explain the fact that many risk behaviors tend to peak in adolescence?

5. *STU7F: they say that most teens know plenty about the dangers of risktaking behaviors like drinking, smoking, and taking drugs, but they ignore on purpose what they have learned

6. *STU14F: this is not true, it is the influence of peers. Steinberg and Morris said that the presence of peers increased risk taking by $50 \%$ in adolescence

7. ${ }_{\mathrm{TEACH}}$ : why do their presence (lof peers) increase risk taking in adolescence?

8. *STU14F: when they are not around peers, adolescents are much better at controlling impulsive or risky behaviors

\section{[...]}

In example 2, the topic of the discussion between teacher and students is "risk behaviours in adolescence". In line 3, (in Italic in the excerpt) the teacher asks a SPECIFIC QUESTION to her students related to one of the best-known grand theories of adolescent development, namely, the theory of adolescent development and psychological functioning proposed by Laurence Steinberg and Amanda S. Morris (Steinberg \& Morris, 2001). In this case, the teacher's question favours the beginning of an argumentative discussion initially between two students who clearly have to different opinions, STU7F and STU14F, and that will involve also other students afterwards. In line 7 the teacher asks a why- question to her student (STU14F). With this question, the teacher is asking her student to advance arguments in support of the assertion she previously made in line 6 . In line 8 , the student replies to the teacher by advancing an argument in support of her previous assertion. This discussion on the effects of family relationships on the adolescent development will continue involving also other students afterwards.

\section{Discussion}

In order to provide a further contribution to the study of argumentative practices in the learning contexts, this study set out to investigate the teacher's questions to their students during argumentative disciplinary discussions in the classroom, i.e., task-related argumentative discussions concerning the discipline taught in the course, with the aim to compare the types of questions used at undergraduate and graduate levels. The results of this study indicate that at the undergraduate level the teacher in most cases asks questions that can favor a large discussion with and among students, and they are not focused on limited, specific aspects of a theory. Rather, the teacher's questions aim to favor a discussion around a more general topic related to the discipline taught in the course, i.e., Developmental Psychology (BROAD QUESTIONS). On the contrary, we have seen that at the graduate level the teacher in most cases asks questions that refer to specific aspects of a certain theory (SPECIFIC QUESTIONS).

Among the many reasons than can at different degrees explain the differences in the types of questions used by the teacher at undergraduate and graduate level, I will focus on one aspect that I think might contribute to clarify the reasons underlying these results. I refer to the actual knowledge by students of the discipline taught in the course, i.e., Developmental Psychology. Despite undergraduate and graduate students - according to their own perception - claim to have a similar knowledge in 
Developmental Psychology (graduate students $\mathrm{M}=$ 7.25 vs. graduate students $M=6.35$ ), in line with the results obtained by previous studies (e.g., Kelly \& Takao, 2002; Means \& Voss, 1996; Osborne, 2005) the observations of the topics treated during the lessons, of the student-teacher and student to student interactions suggest that the younger students had an actual knowledge of the discipline much lower than younger students, even more than what was claimed in the answers to the questionnaire. In most cases, in fact, the arguments used by the undergraduate students referred to a well-known theory, however avoiding to mention the correct term of the scientific notion they refer to. In the corpus, I observed that the knowledge in Developmental Psychology of the graduate students was more detailed compared to graduate students. For example, in the excerpt 2 we have seen that the graduate students were able to advance arguments that refer to well-specific aspects of a scientific theory, i.e., the theory of adolescent development by Steinberg and Morris, to support their own standpoints. Moreover, the graduate students were also able to engage in argumentative discussions relating to the different theories that treat limited aspects of a certain topic discussed during the lessons.

The creation by teacher of situations in which it makes sense for students to freely engage with one another's ideas is a clear-cut example of how students have a chance to learn from disciplinary argumentative discussions (e.g., important theories, laws, models, or concepts). How do these results relate to actual crucial questions involving learning and argumentation? From a learning perspective, the results of this study bring to light the crucial importance of a teachers' training aimed at making teachers aware of the role of questions in promoting effective argumentation among students. The learning benefit for students resides in being active participant in the argumentative process of construction of new knowledge, and not only listeners (Baker, 2009). The literature has already demonstrated that discussing about a certain topic is more effec- tive than only listening it (e.g., Chin \& Osborne, 2010; Nussbaum \& Sinatra, 2003; Schwarz et al., 2000; Wiley \& Voss, 1999). In agreement with other scholars (Ford, 2008; Kuhn, 1993; Newton et al., 1999), if students are not empowered to criticize the ideas being discussed then they must accept the ideas that sound plausible and/or are held by the individual with the most clout. From an argumentative perspective, this study shows how the contextualization of argumentation (van Eemeren, 2010, 2011) is fundamental in the study of school contexts. The use of argumentation theories and analytical models cannot consider the context as given: it is needed to focus the investigation on the interactions between teachers and students in the classroom in order to properly analyse the argumentative dynamics occurring in the classroom. In particular, the argumentative roles (see van Eemeren \& Grootendorst, 2004, pp.59-62), e.g. protagonist/antagonist, played by the teacher and the students and the interpersonal and institutional constraints (van Eemeren, 2011) on the argumentative interactions in the classroom imposed by the school contexts are two aspects that certainly still need further detailed investigations.

Even though the present study provides new insights of the argumentative interactions between students and teacher in the learning contexts of higher education, I need to address several limitations. A first limitation involves the presence of a video camera in the classroom. Although it is possible that the presence of a video camera may have influenced student behavior, it is difficult to predict in which direction. Informal observation, however, suggested that students in both conditions were very attentive and were highly engaged as they worked. A second limitation involves the limited number of recordings that, on the one hand, have favored a more careful analysis but, on the other hand, did not allow certain quantifications such as the correlation between categories. A larger database would probably permit more quantitatively reliable data for certain statistical relationships. Using a natural setting does not automatically solve the problem of obtain- 
Promoting learning and development of students through argumentative interactions....

ing optimal data. Nevertheless, the interactions between students and teacher in the learning contexts of higher education are an invaluable source for the investigation of the argumentative dynamics in the classroom within an emic perspective.

\section{Acknowledgements}

This work was supported by the Swiss National Science Foundation under Grant number P2TIP1_148347.

\section{Notes}

The Eurydice Network provides information on and analyses of European education systems and policies. As from 2013 it consists of 40 national units based in all 36 countries participating in the EU's Lifelong Learning programme. It is co-ordinated and managed by the EU Education, Audiovisual and Culture Executive Agency (EACEA) in Brussels, which drafts its studies and provides a range of online resources. For more information, see http://eacea.ec.europa.eu/education/eurydice/index en.php

\section{References}

- Alexander, P. A., Kulikowich, J. M., \& Schulze, S. K. (1994). The influence of topic knowledge, domain knowledge, and interest on the comprehension of scientific exposition. Learning and Individual Differences, 6(4), 379-397.

- Alexopoulou, E., \& Driver, R. (1996). Small-group discussion in physics: Peer interaction modes in pairs and fours. Journal of Research in Science Teaching, 33(10), 1099-1114.

- Anderson, R. C., Chinn, C. A., Chang, J., Waggoner, M., \& Yi, H. (1997). On the logical integrity of children's arguments. Cognition and Instruction, 15(2), 135-167.

- Andrews, R. (2009). A case study of argumentation at undergraduate level in History. Argumentation. Special Issue on Argumentation and Education: Studies from England and Scandinavia, 23(4), 547-548.

- APA. (2009). Publication manual of the American Psychological Association (6th ed.). Washington, DC: American Psychological Association.

- Baker, M. (2002). Argumentative interactions, discursive operations and learning to model in science. In P. Brna, M. Baker, K. Stenning, \& A. Tiberghien (Eds.), The role of communication in learning to model (pp. 303-324). Mahwah, NJ: Lawrence Erlbaum.

- Bova, A., \& Arcidiacono, F. (2013). Investigating children's Why-questions. A study comparing argumentative and explanatory function. Discourse Studies, 15(6): 713-734.

- Bova, A., \& Arcidiacono, F. (2014). "You must eat the salad because it is nutritious". Argumentative strategies adopted by parents and children in food-related discussions at mealtimes. Appetite, 73, 81-94.

- Bova, A., \& Arcidiacono, F. (2015). Beyond conflicts. Origin and types of issues leading to argumentative discussions during family mealtimes. Journal of Language Aggression and Conflict, 3(2).

- Buty, C., \& Plantin, C. (2008). Argumenter en classe de sciences. Du débat a l’apprentissage. Lyon: INRP.

- Chin, C., \& Osborne, J. (2010). Supporting argumentation through students' questions: Case studies in science classrooms. Journal of the Learning Sciences, 19(2), 230-284. 
- Chouinard, M.M., Harris, P.L., \& Maratsos, M.P. (2007). Children's Questions: A Mechanism for Cognitive Development. Boston, MA: Blackwell.

- Driver, R., P. Newton, \& Osborne, J. (2000). Establishing the norms of scientific argumentation in classrooms. Science Education, 84(3), 287-312.

- Duschl, R., \& Osborne, J. (2002). Supporting and promoting argumentation discourse in science education. Studies in Science Education, 38(1), 39-72.

- van Eemeren, F H. (2010). Strategic maneuvering in argumentative discourse. Amsterdam: John Benjamins.

- van Eemeren, F.H. (2011). In context. Giving contextualization its rightful place in the study of argumentation. Argumentation, 25(2), 141-161.

- van Eemeren, F.H., \& Grootendorst, R. (2004). A systematic theory of argumentation: The pragma-dialectical approach. Cambridge: Cambridge University Press.

- Erduran, S., \& Jiménez-Aleixandre, M. P. (2007). Argumentation in science education: Perspectives from classroom-based research. Dordrecht: Springer.

- Eurydice. (2011). Science education in Europe: National policies, practices and research. Brussels: EACEA. doi: $10.2797 / 7170$

- Ford, M. (2008). Disciplinary authority and accountability in scientific practice and learning. Science Education, 92(3), 404-423.

- Frazier, B.N., Gelman, S.A., \& Wellman, H.M. (2009). Preschoolers' search for explanatory information within adult: Child conversation. Child Development, 80(6), 1592-1611.

- Garcia-Mila, M., \& Andersen, C. (2007). Cognitive foundations of learning argumentation. In S. Erduran, \& M. P. Jiménez-Aleixandre (Eds.), Argumentation in science education: Perspectives from classroom-based research (pp. 28-44). Dordrecht: Springer.

- Hogan, K., \& Maglienti, M. (2001). Comparing the epistemological underpinnings of students and scientists reasoning about conclusions. Journal of Research in Science Teaching, 38(6), 663-687.

- Jiménez-Aleixandre, M. P. (2007). Designing argumentation learning environments. In S. Erduran, \& M. P. Jiménez-Aleixandre (Eds.), Argumentation in science education: Perspectives from classroom-based research (pp. 89-113). Dordrecht: Springer.

- Jiménez-Aleixandre, M.P., Rodriguez, A.B., \& Duschl, R.A. (2000). “Doing the lesson' or “Doing science': Argument in high school genetics. Science Education, 84(6), 757-792.

- Kelly, G. J., \& Chen, C. (1999). The sound of music: Constructing science as sociocultural practices through oral and written discourse. Journal of Research in Science Teaching, 36(8), 883-915.

- Kelly, G., \& Takao, A. (2002). Epistemic levels in argument: An analysis of university oceanography students' use of evidence in writing. Science Education, 86(3), 314-342.

- Kuhn, D. (1991). The skills of argument. New York, NY: Cambridge University Press.

- Kuhn, D. (1993). Science as argument: implications for teaching and learning scientific thinking. Science Education, 77(3), 319-337.

- Kuhn, D., \& Udell, W. (2003). The development of argument skills. Child Development, 74(5), 1245-1260. 
Promoting learning and development of students through argumentative interactions....

- López-Facal, R., Jiménez-Aleixandre, M. P., \& Arcidiacono, F. (2015). Le territoire comme composante de l'identification nationale dans l'argumentation des élèves du secondaire. In N. Muller Mirza \& C. Buty (Eds.), Argumentation dans les contextes de léducation (pp. 323-354). Bern: Lang.

- Macagno, F., \& Konstantinidou, A. (2013). What students' arguments can tell us: Using argumentation schemes in science education. Argumentation, 27(3), 225-243.

- MacWhinney, B. (2000). The child project: Computational tools for analyzing talk. Pittsburgh, PA: Routledge.

- Mason, L. (2001). Introducing talk and writing for conceptual change: A classroom study. Learning and Instruction, 11(6), 305-329.

- McNeill, K. L., \& Krajcik, J. (2009). Synergy between teacher practices and curricular scaffolds to support students in using domain specific and domain general knowledge in writing arguments to explain phenomena. Journal of the Learning Sciences, 18(3), 416-460.

- Means, M.L., \& Voss, J.F. (1996). Who reason well? Two studies of informal reasoning among children of different grade, ability, and knowledge levels. Cognition and Instruction, 14(2), 139-178.

- Muller Mirza, N., \& Perret-Clermont, A.-N. (Eds.) (2009). Argumentation and education. New York, NY: Springer.

- Muller Mirza, N., \& Perret-Clermont, A.-N., Tartas, V., \& Iannaccone, A. (2009). Psychosocial processes in argumentation. In N. Muller Mirza, \& A.-N. Perret-Clermont (Eds.), Argumentation and education (pp. 6790). New York, NY: Springer.

- Newton, P., Driver, R., \& Osborne, J. (1999). The place of argument in the pedagogy of school science. International Journal of Science Education, 21(5), 553-576.

- Nussbaum, E. M., \& Sinatra, G. M. (2003). Argument and conceptual engagement. Contemporary Educational Psychology, 28(3), 384-395.

- Nussbaum, E. M., \& Schraw, G. (2007). Promoting argument-counterargument integration in students` writing. The Journal of Experimental Education, 76(1), 59-92.

- Osborne, J. (2005). The role of argument in science education. In K. Boersma, M. Goedhart, O. de Jong, \& H. Eijkelhof (Eds.), Research and the Quality of Science Education (pp. 367-380). Dordrecht: Springer.

- Sadler, T. D. (2006). Promoting discourse and argumentation in science teacher education. Journal of Science Teacher Education, 17(4), 323-346.

- Sampson, V., \& Clark, D. (2008). Assessment of the ways students generate arguments in science education: Current perspectives and recommendations for future directions. Science Education, 92(3), 447-472.

- Sandoval, W. A., \& Reiser, B. J. (2004). Explanation-driven inquiry: Integrating conceptual and epistemic scaffolds for scientific inquiry. Science Education, 88(3), 345-372.

- Schwarz, B. B. (2009). Argumentation and learning. In N. Muller Mirza \& A.-N. Perret-Clermont (Eds.), Argumentation and education (pp. 91-126). New York, NY: Springer.

- Schwarz, B. B., \& Linchevski, L. (2007). The role of task design and argumentation in cognitive development during peer interaction: The case of proportional reasoning. Learning and Instruction, 17(5), 310-331.

- Schwarz, B. B., Neuman, Y., \& Biezuner, S. (2000). Two wrongs may make a right...if they argue! Cognition and Instruction, 18(4), 461-494. 
- Simon, S., Erduran, S., \& Osborne, J. (2006). Learning to teach argumentation: Research and development in the science classroom. International Journal of Science Education, 28(2), 235-260.

- Steinberg L, \& Morris A.S. (2001). Adolescent development. Annual Review of Psychology, 52, 83-110.

- Wiley, J., \& Voss, J. F. (1999). Constructing arguments from multiple sources: Tasks that promote understanding and not just memory for text. Journal of Educational Psychology, 91(2), 301-311.

- Voss, J. F., \& van Dyke, J. A. (2001). Argumentation in psychology: Background comments. Discourse Processes, 32(2-3), 89-111.

- Zohar, A., \& Nemet, F. (2002). Fostering students' knowledge and argumentation skills through dilemmas in human genetics. Journal of Research in Science Teaching, 39(1), 35-62.

\section{Appendix}

\section{Transcription conventions}

$\begin{array}{ll}* & \text { indicates the speaker's turn } \\ {[\ldots]} & \text { not-transcribed segment of talking } \\ , & \text { continuing intonation } \\ . & \text { falling intonation } \\ : & \text { prolonging of sounds } \\ ? & \text { rising intonation } \\ ! & \text { exclamatory intonation } \\ \% \text { pau: } & \text { pause of } 2.5 \mathrm{sec}\end{array}$


Promoting learning and development of students through argumentative interactions....

\title{
др Антонио Бова
}

Одсек за психологију, Универзитет у Утрехту, Холандија

\author{
Промовисање учења и развоја студената кроз аргументовану интеракцију \\ - студија питања наставника у контексту учења у оквиру високог образовања
}

Аргументована дискусија омогућава студентима да се ангажују у конструсању знања, да помере фокус са рутинског меморисања чињеница и теорија на сложену научну праксу којом конструишу и оправдавају захтеве знања. Иначе, за разлику од аргументоване дискусије у неформалном окружењу, као што је окупљање породице за време оброка, аргументована дискусија у контексту учења се ретко одвија спонтано. Аргументоване дискусије које се тичу научних дисиплина у учионици, то јест дискусије које се односе на задатке на часу у вези са научном дисциплином треба да се експлицитно промовишу кроз стратегије учења које подржавају интеракцију између студената и интеракцију између студената и наставника. Сходно томе, улога наставника је главна у циљу подстицања учешћа студента у аргументованој дискусији.

Ова студија има за циљ да својим резултатима допринесе постојећој литератури која се тиче аргументоване дискусије у контексту учења у високом образовању. Она се посебно усредсређује на питања коју упућују наставници својим студентима у току аргуметоване дискусије у вези са научним дисциплинама у разреду ради упоређивања свих питања која постављају наставници на основним и дипломским нивоима студирања. Корпус података се састоји од шеснаест снимљених часова два курса - једног на основним студијама, а другог на дипломским студијама, а тичу се развојне психологије. Два курса су изабрана према следећим критеријумима: 1) сличан број студената; 2) сличан домен научне дисциплине; 3) оба курса држи исти наставник на енглеском језику. Аналитички приступ идентификацији аргументоване дискусије је прагма-дијалектички идеал модела критичке дискусије. Овај модел представља идеалну дефиницију аргументације која се развила према логичном стандарду: аргументована дискусија почиње када говорник развија своје мишљење, а слушалац сумња или директно напада ставове говорника. Сходно томе, конфронтација, по којој се неслагање које се тиче одређене тачке гледишта развија у дискурзивној размени или коју говорник прихвата, јесте неопходан услов да се развија аргументована дискусија.

Резултати ове студије указују на чињеницу да, на нивоу основних студија, наставник у већини случајева поставља питања која доводе до широке дискусије међу студентима, а која нису усредсређена на ограничене, посебне аспекте теорије. Пре питања наставника имају за циљ да задрже дискусију око општијих питања која се тичу одређене научне дисциплине, као што је, на пример, развојна психологија (питања широког спектра). Напротив, на нивоу дипломских студија, наставник у већини случајева поставља питања која се односе на посебне аспекте одређене теорије (специфична питања). Главни разлог који може да допринесе објашњавању ових резултата је право знање студената у вези са научном дисциплином која се проучава на курсу, то јест са развојном психологијом. Опсервација тема које се обрађују током часова, а што се уочава у интеракцији, указује да су млађи студенти имали мање знања о теоријским дисциплинама које су се обрађивале. У већини случајева, аргументи које користе студенти на основним студијама се односе на познате теорије, а избегавају да употребе прави термин научне идеје на коју се односе. С друге стране, студенти дипломци су били у могућности да дају аргументе 
који се односе на посебне аспекте научне теорије, као и да се укључе у аргументоване дискусије које се односе на различите теорије које су имале ограничене аспекте тема о којима се дискутовало у току часа.

Из перспективе учења, резултати ове студије бацају светло на најважније аспекте професионалног усавршавања наставника које имају за циљ да наставници буду свесни улоге питања у промовисању ефективне аргументације међу студентима. Добробит учења за студенте лежи у томе да у аргументованом процесу конструкције новог знања буду активни учесници, а не само слушаоци. Наставници креирају ситуације које подстичу студенте да се упусте у аргументовану расправу, и то представља пример како студенти могу да уче из аргументованих дискусија одређених научних дисциплина (на пример, важне теорије, закони, модели или концепти). Из перспективе аргументоване дискусије, ова студија показује како контекстуализација аргумента представља основу за студију у школском контексту. Употреба аргументационе теорије и аналитичких модела не може да узме у обзир дати контекст: потребно је да се усредсреди на интеракцију између наставника и студента у учионици ради подробне анализе аргументационе динамике која се одвија у учионици.

Кључне речи: Аргументација, високо образовање, квалитативна истраживања, интеракција између наставника и студената, питања наставника. 